\title{
Hepatic scintigraphy in management of infants and children with liver disease
}

\author{
ARNOLD L. SMITH, ALEX P. MOWAT, AND ROGER WILLIAMS \\ From the Liver Unit and Department of Child Health, King's College Hospital Medical School, London
}

SUMMARY Scintiscans of liver and spleen using technetium 99m sulphur colloid in 15 infants with extrahepatic biliary atresia and 11 infants with severe obstructive jaundice ( 7 with genetic deficiency of $\alpha_{1}$-antitrypsin) showed similar hepatic size, pattern of isotope uptake, and splenic abnormality with no distinguishing features. In 37 older children with a variety of liver disorders, the scan was invaluable in showing filling defects in five instances. Selenomethionine was taken up not only by the two filling defects due to hepatoblastoma but also in a haemangioendothelioma. In the remaining patients liver scanning confirmed hepatic abnormality and the necessity for more specific invasive diagnostic investigations.

In the investigation of adults with liver disease, hepatic scintiscanning after intravenous administration of colloidal technetium sulphide $\left({ }^{99 \mathrm{~m}} \mathrm{Tc}\right)$ is considered valuable because of its simple noninvasive nature and its well documented validity. It has been shown to be particularly important in the management of primary and secondary malignant disease of the liver and to a lesser extent in parenchymal focal and infiltrative disorders, and also in indicating possible extrahepatic biliary obstruction by diminished isotope uptake in the region of the portahepatis (Drum and Christacopoulos, 1972).

In children hepatic scintiscanning has been used in the management of hepatic tumour (Piepsz et al., 1974), in chronic granulomatous disease (Samuels, 1971), and also for showing hepatic enlargement and possible abnormality in cystic fibrosis (Feigelson et al., 1972; Goodchild et al., 1975). We are aware of no report of its systematic evaluation in infants and children with a variety of liver disorders, and therefore record our findings and assessment of the value of scanning in the management of 26 infants with obstructive liver disease and 37 children with clearly defined hepatic disorders.

\section{Patients and methods}

Thirteen patients ranging in age from 4 to 20 weeks and 2 patients aged 39 and 69 weeks had extrahepatic biliary atresia proven at laparotomy. 11 infants ranging in age from 8-24 weeks had severe

Received 7 January 1977 obstructive jaundice with clinical and biochemical features similar to the above, but attributed to hepatitis on the basis of the liver biopsy findings, Rose Bengal excretion $>10 \%$, and subsequent complete clearing of jaundice. 7 of these had genetic deficiency of the serum protein $\alpha_{1}$-antitrypsin. In the remainder no cause was identified.

Of the older children, 8 had chronic active hepatitis, 8 cirrhosis of varying causes, 3 cystic fibrosis with hepatosplenomegaly and abnormal liver function tests, 2 congenital hepatic fibrosis, 2 glycogen storage disease, and 9 extrahepatic portal hypertension. In all of these the diagnosis had been confirmed by histological examination of the liver, together with appropriate immunological, biochemical, and radiological investigations. Scans from 5 children with space-occupying defects in the liver were also examined. 2 of these had hepatoblastoma, 1 rhabdomyosarcoma, one haemangioendothelioma, and 1 hydatid cyst.

Scanning was performed 15-30 minutes after the intravenous injection of ${ }^{99 \mathrm{mTc}}$ in a dose of $250 \mu \mathrm{Ci}$ for infants and $20-40 \mu \mathrm{Ci} / \mathrm{kg}$ for older children. With the child lying supine, a Picker Rectilinear Scintiscanner was set up over the area of maximum gamma radiation, which is recorded as the peak count rate. The gamma radiation from the liver is represented by coloured dots which vary in colour with the intensity of radiation and thus indicate the special distribution and concentration of the isotope within the liver as well as showing liver shape and size. The position of the costal margin and the lower edge of the liver when palpable is marked on the 
Table $1{ }^{95 m}$ Tc liver scans in infants with extrahepatic biliary atresia and in infants with obstructive jaundice due to neonatal hepatitis

\begin{tabular}{|c|c|c|c|c|c|c|c|c|c|c|c|c|c|}
\hline \multirow[b]{2}{*}{$\begin{array}{l}\text { Case } \\
\text { no. }\end{array}$} & \multirow[b]{2}{*}{$\begin{array}{l}\text { Age } \\
(w)\end{array}$} & \multirow{2}{*}{$\begin{array}{l}\text { Isotope } \\
\text { dose } \\
(\mu \mathrm{Ci})\end{array}$} & \multirow[b]{2}{*}{$\begin{array}{l}P C R \\
\text { (in } 1000 \\
\text { counts } / \text { min) }\end{array}$} & \multirow{2}{*}{$\begin{array}{l}\text { Clinical } \\
\text { enlargement } \\
\text { of liver } \\
\text { below } \\
\text { costal } \\
\text { margin } \\
(\mathrm{cm})\end{array}$} & \multicolumn{2}{|c|}{$\begin{array}{l}\text { Dimensions of } \\
\text { liver on scan }\end{array}$} & \multirow{2}{*}{$\begin{array}{l}\text { Area of } \\
\text { liver on } \\
\text { scan by } \\
\text { planimetry } \\
\left(\mathrm{cm}^{2}\right)\end{array}$} & \multirow{2}{*}{$\begin{array}{l}\text { Subiective } \\
\text { enlargement } \\
\text { of liver } \\
\text { on scan }\end{array}$} & \multirow{2}{*}{$\begin{array}{l}\text { Uneven } \\
\text { uptake } \\
\text { of } \\
\text { isotope }\end{array}$} & \multirow[b]{2}{*}{$\begin{array}{l}\text { Hilar } \\
\text { defect }\end{array}$} & \multirow{2}{*}{$\begin{array}{l}\text { Clinical } \\
\text { enlargement } \\
\text { of spleen } \\
\text { below } \\
\text { costal } \\
\text { margin } \\
(\mathrm{cm})\end{array}$} & \multirow{2}{*}{$\begin{array}{l}\text { Spleen } \\
\text { size on } \\
\text { scan } \\
(\mathrm{cm})\end{array}$} & \multirow{2}{*}{$\begin{array}{l}\text { Splenic } \\
\text { uptake } \\
\text { on } \\
\text { scan }\end{array}$} \\
\hline & & & & & $\begin{array}{l}\text { Max } \\
\text { width }\end{array}$ & $\begin{array}{l}\text { vertical } \\
\text { axis }\end{array}$ & & & & & & & \\
\hline (a) $I$ & \multicolumn{13}{|c|}{ Infants with $E H B A$} \\
\hline 1 & 14 & 250 & 40 & 10 & 14 & 10 & 85 & Yes & No & No & No & Not seen & None \\
\hline 2 & 20 & 250 & $\begin{array}{l}\text { Not } \\
\text { recorded }\end{array}$ & 6 & 13 & 12 & 88 & No & No & , & 3 & $4 \times 6$ & Low \\
\hline 3 & 8 & 150 & 24 & 6 & 12 & 8 & 65 & Yes & Marked & , , & 4 & Not seen & None \\
\hline 4 & 17 & 250 & 80 & 8 & 11 & 9 & 64 & Yes & No & ," & 3 & , & , \\
\hline 5 & 4 & 250 & 80 & 2 & 8 & $8(6)$ & 55 & No & , & ", & No & ," & ", \\
\hline 6 & 7 & 250 & 60 & $3 \cdot 5$ & 10 & 8 & 49 & Yes & , & ", & No & ," & $"$ \\
\hline 7 & 6 & 250 & 60 & 4 & $12(8)$ & 8 & 60 & No & ", & ", & 3 & $6 \times 4$ & $\begin{array}{c}\text { Moderate } \\
<\text { liver }\end{array}$ \\
\hline 8 & 7 & 250 & 40 & 3 & 8 & 6 & 49 & No & , & ", & No & Not seen & None \\
\hline 9 & 8 & 250 & 80 & 6 & 9 & 9 & 64 & Yes & , & , & 8 & ", & ", \\
\hline 10 & 11 & 250 & 59 & 3 & 11 & 10 & 59 & Yes & ", & $"$ & No & Not enlarged & Very low \\
\hline 11 & 8 & 250 & 60 & 4 & 11 & 10 & 62 & Yes & & $"$ & No & , & ," \\
\hline 12 & 9 & 250 & 36 & 6 & 7 & 5 & 22 & No & $\begin{array}{l}\text { Mild } \\
(2 / 3)\end{array}$ & 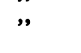 & $1-2$ & Not seen & None \\
\hline 13 & 16 & 500 & 60 & 7 & 10 & 10 & 61 & Yes & No & ", & 3 & Not enlarged & Low \\
\hline 14 & 39 & 200 & 22 & 4 & $11(9)$ & 8 & 44 & No & $\begin{array}{l}\text { Mild } \\
(2 / 3)\end{array}$ & " & 10 & $7 \times 4$ & $\begin{array}{l}\text { Marked, } \\
\text { >liver }\end{array}$ \\
\hline 15 & 69 & 500 & 20 & 6 & 12 & 8 & 57 & Small & Mild & ", & 10 & $9 \times 4$ & $\begin{array}{l}\text { Marked, } \\
>\text { liver }\end{array}$ \\
\hline \multicolumn{14}{|c|}{ (b) Infants with neonatal hepatitis } \\
\hline 16 & 8 & 250 & 120 & 7 & 7 & 8 & 76 & Yes & Mild & No & No & Normal & Low \\
\hline 17 & 9 & 250 & 60 & 6 & 14 & 9 & 85 & Yes & No & , & No & Not seen & None \\
\hline 18 & 16 & 250 & 50 & 3 & $10(8)$ & 8 & 42 & No & $\begin{array}{l}\text { Mild } \\
(2 / 3)\end{array}$ & , & 2 & Normal & Low \\
\hline 19 & 12 & 250 & 15 & 6 & 11 & 10 & 72 & Yes & No & ", & 7 & Not seen & None \\
\hline \multicolumn{14}{|c|}{$\alpha_{1}$-antitrypsin-deficient } \\
\hline 20 & 24 & 250 & 24 & 5 & 13 & 9 & 74 & No & $\begin{array}{l}\text { Mild } \\
(2 / 3)\end{array}$ & ", & 2 & Not seen & None \\
\hline 21 & 10 & 250 & 80 & 5 & $9(11)$ & 9 & 55 & Yes & No & & & Not seen & None \\
\hline 22 & 24 & 200 & 100 & 3 & 12 & 8 & 62 & No & No & 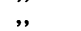 & , & Normal & Low \\
\hline 23 & 16 & 250 & 80 & 4 & 9 & 7 & 50 & Yes & No & ", & ", & Not seen & None \\
\hline 24 & 14 & 250 & 50 & 2 & 9 & 10 & 60 & Yes & $\begin{array}{l}\text { Mild } \\
(2 / 3)\end{array}$ & $"$ & " & , & ", \\
\hline $\begin{array}{l}25 \\
26\end{array}$ & 13 & 250 & 40 & 4 & 7 & 7 & 32 & No & Mild & ", & ," & ", & , \\
\hline 26 & 14 & 250 & 70 & 4 & 10 & 7 & 37 & No & Mild & ", & , & , & ", \\
\hline
\end{tabular}

$P C R=$ peak count rate .

scan. The coloured dot scan so produced was assessed independently for the following criteria: overall dimensions, subjective evidence of hepatic enlargement, evenness of hepatic uptake of isotope, filling defects, splenic size, and splenic uptake. The area of the liver scan was measured by planimetry. Where a space-occupying lesion was seen on the ${ }^{99 m} \mathrm{Tc}$ scan, a selenomethionine scintiscan was performed and assessed in conjunction with the $99 \mathrm{mTc}$ scan. A.P.M. assessed the scans without knowledge of the clinical data.

\section{Results}

In the scans from infants with obstructive jaundice, interobserver error was limited to minor differences in the assessment of the evenness of hepatic uptake in 5 of 26 scans within each instance, one observer differing from his two colleagues. Difficulties also arose in measuring the exact hepatic size since the edge of the liver scan was not clear cut and the exact dimensions are therefore imprecise, but only where two values are shown in Table 1 (Figs. 1,2) were differences of more than $1 \mathrm{~cm}$ found. Good agreement of assessment was found in the scans of older children.

In infants with hepatitis or biliary atresia the hepatic vertical length, width, and areas were not significantly different, the mean values $( \pm \mathrm{SE})$ being in hepatitis $10 \pm 0 \cdot 7,8 \cdot 4 \pm 0 \cdot 3$, and $58 \cdot 6 \pm 5 \cdot 2$ respectively, and in biliary atresia $10 \cdot 6 \pm 0 \cdot 5$, $8 \cdot 6 \pm 0 \cdot 4$, and $59 \pm 4$. The peak count rates showed no differences: hepatitis $62 \cdot 6 \pm 9 \cdot 5$, atresia $51 \cdot 5 \pm$ $5 \cdot 7$. The subjective assessment of uneven hepatic uptake occurred with similar frequency in both groups. No filling defects were seen in the area of 


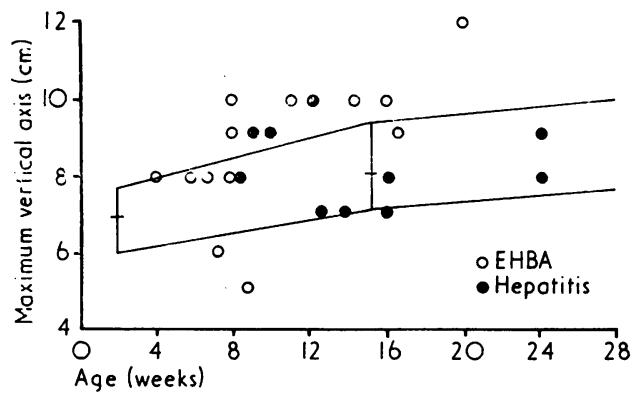

Fig. 1 Relationship between age of patient and the maximum vertical axis of the liver in extrahepatic biliary atresia (EHBA), and in neonatal hepatitis, compared with values from normal infants as assessed by straight $\mathrm{x}$-ray of the abdomen by Deligeorgis et al. (1973).

the portahepatis in either group. Although palpable spleen and measurable splenomegaly were found more commonly in biliary atresia, the pattern of splenic uptake was similar in the two groups of patients except in the 2 patients with biliary atresia aged more than 36 months, in which the splenic isotope uptake was greater than hepatic uptake. No differences were noted in the scan appearances in those infants with severe idiopathic hepatitis as compared with the 7 who had deficiency of $\alpha_{1}$-antitrypsin.

Children with chronic liver disease. 8 children with chronic active hepatitis without cirrhosis showed even isotope uptake, a normal peak count rate, and minimal splenic enlargement or isotope uptake. The liver was usually considered to be large (Table 2). In contrast, those with established cirrhosis showed normal or small livers with a patchy isotope uptake and low peak count rate with moderate splenomegaly but a marked increase in splenic isotope

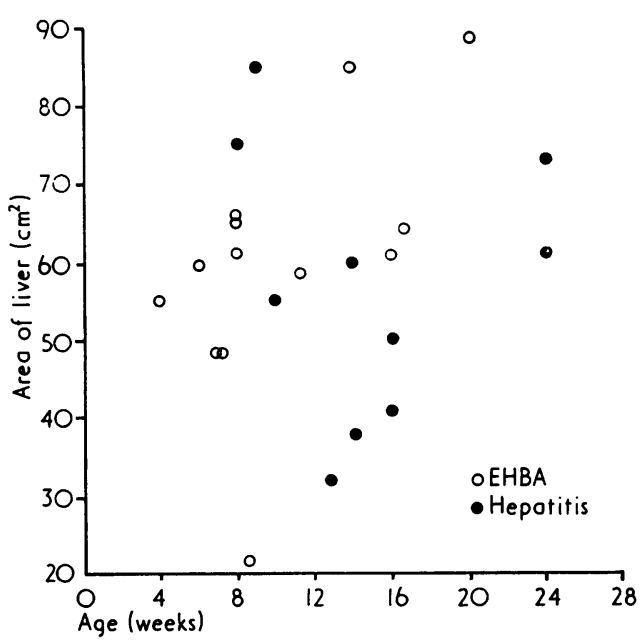

Fig. 2 Relationship between age of patient and liver scan area by planimetry for EHBA and hepatitis.

uptake, in some cases exceeding that of the liver. The appearance in cystic fibrosis was similar to that in cirrhosis except in one instance the liver was enlarged and the peak count rate normal.

The scans from the 2 patients with congenital hepatic fibrosis both were large with a finely mottled appearance and a normal peak count rate. In both there was marked splenic enlargement and increased uptake. The scans from the 2 children with glycogen storage disease had a normal or reduced peak count rate with a patchy hepatic uptake and minimal splenic enlargement. 6 of 9 children with extrahepatic portal hypertension had small livers with even isotope uptake and a normal peak count rate. There was marked splenomegaly and a relatively low splenic uptake of the isotope. In all 5 children

Table $2{ }^{99 m}$ Tc liver scan in children with liver disorders

\begin{tabular}{|c|c|c|c|c|c|c|c|c|}
\hline \multirow[b]{2}{*}{ Disorder } & \multirow{2}{*}{$\begin{array}{l}\text { No. of } \\
\text { patients }\end{array}$} & \multicolumn{3}{|c|}{$\begin{array}{l}\text { Subiective assessment } \\
\text { of liver size }\end{array}$} & \multirow{2}{*}{$\begin{array}{l}\text { Nature of } \\
\text { isotope uptake }\end{array}$} & \multirow{2}{*}{$\begin{array}{l}\text { Peak count } \\
\text { rate }\end{array}$} & \multirow{2}{*}{$\begin{array}{l}\text { Splenic } \\
\text { size }\end{array}$} & \multirow{2}{*}{$\begin{array}{l}\text { Splenic } \\
\text { uptake }\end{array}$} \\
\hline & & Small & Normal & Large & & & & \\
\hline \multicolumn{9}{|l|}{ Chronic active } \\
\hline $\begin{array}{l}\text { hepatitis } \\
\text { Cirrhosis }\end{array}$ & $\begin{array}{l}8 \\
8\end{array}$ & $\begin{array}{l}1 \\
6\end{array}$ & $\begin{array}{l}3 \\
2\end{array}$ & 4 & $\begin{array}{l}\text { Homogeneous } \\
\text { Mottled }\end{array}$ & $\begin{array}{l}\text { Normal } \\
\text { Reduced }\end{array}$ & $\begin{array}{l}\text { Slight increase } \\
\text { Moderate enlargement }\end{array}$ & $\begin{array}{l}\text { Normal } \\
\text { Markedly increased }\end{array}$ \\
\hline Cystic fibrosis & 3 & 1 & 1 & 1 & Mottled & $\begin{array}{l}\text { Normal or } \\
\text { reduced }\end{array}$ & Moderate enlargement & $\begin{array}{l}\text { Moderately } \\
\text { increased }\end{array}$ \\
\hline $\begin{array}{l}\text { Congenital hepatic } \\
\text { fibrosis }\end{array}$ & 2 & 0 & 0 & 2 & Finely mottled & Normal & Markedly increased & $\begin{array}{c}\text { Moderately } \\
\text { increased }\end{array}$ \\
\hline $\begin{array}{l}\text { Glycogen storage } \\
\text { disease }\end{array}$ & 2 & 0 & 0 & 2 & Mottled & $\begin{array}{l}\text { Normal and } \\
\text { reduced }\end{array}$ & Slight increase & Minimal \\
\hline $\begin{array}{l}\text { Extrahepatic portal } \\
\text { hypertension }\end{array}$ & 9 & 6 & 3 & 0 & Homogeneous & Normal & Marked increase & Minimal \\
\hline
\end{tabular}




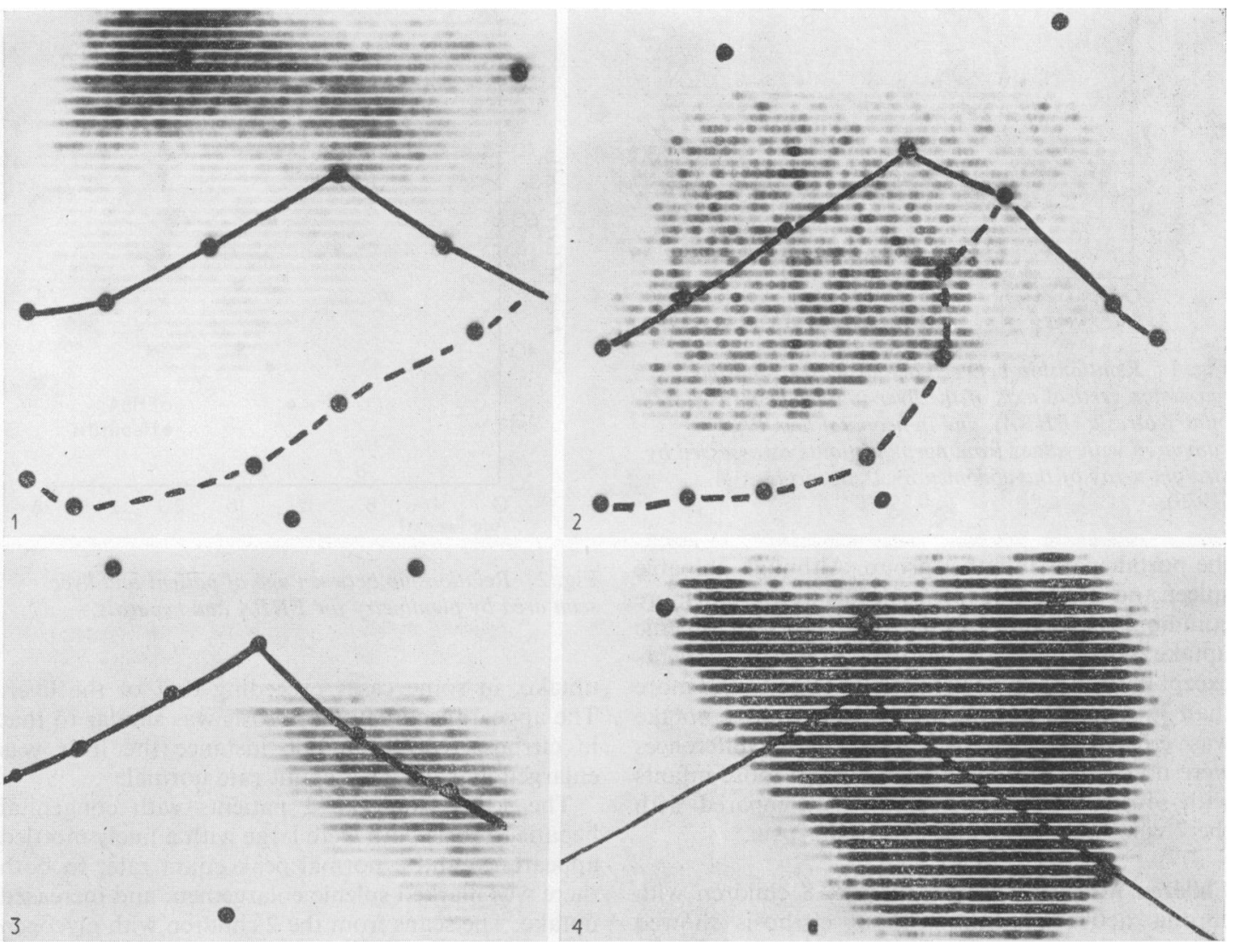

Fig. 3 Photographs of serial liver scans from a 7-month-old child with a large hepatoblastoma involving the major part of the right lobe of liver. The costal margin is indicated by a continuous line and the liver edge, when palpable on clinical examination by a broken line. Nipples and umbilicus are marked . (1) Technetium 99 ( $99 \mathrm{~m}$ Tc) scan $(500 \mu \mathrm{Ci})$ showing large filling defect over the lower left lobe with uptake maximal in the right upper quadrant of the liver (peak count rate 68). (2) Selenomethionine (Se 75) scan on the same day showing uptake over the area of the filling defect. (3) ${ }^{98} \mathrm{~m} T \mathrm{Tc}$ scan $(500 \mu \mathrm{Ci}) 14$ days after exiended right lobectomy, with uptake limited to left lobe of liver or spleen (peak count rate 100). (4) ${ }^{9 ! m} \mathrm{Tc}$ scan $(500 \mu \mathrm{Ci}) 4$ years 5 months after lobectomy (peak count rate 38 ).

with hepatic space-occupying lesions the ${ }^{99 \mathrm{~m} T c}$ scan showed an area of defective uptake. On selenomethionine scanning the isotope was taken up by the filling defect in both patients with hepatoblastoma and the infant with haemangioendothelioma. Selenomethionine was not taken up by the rhabdomyosarcoma or hydatid cyst.

\section{Discussion}

It is disappointing that the $99 \mathrm{~m} \mathrm{Tc}$ radio isotope scan of the liver had no features which distinguish extrahepatic biliary atresia from hepatitis without bile duct obstruction, since these conditions are difficult to distinguish without invasive technique such as liver biopsy, or the time-consuming ${ }^{131}$ I Rose Bengal faecal excretion test. In extrahepatic biliary atresia the scan did not show the filling defect in the region of the portahepatis sometimes seen in adults with bile duct obstruction, presumably since in biliary atresia the intra- and extrahepatic bile ducts above the atretic region rarely dilate. A wide range in hepatic dimensions occurred in both conditions unrelated to the age of the patient or apparent duration of the illness. To avoid misinterpretation due to movement artefact, it is necessary but often difficult to keep young infants still during the 10 minutes it may take to complete the scan. A further possible source of error is extravasation of some of the radioisotope since a very small volume is 
injected. Since the scan in no way influenced clinical management in this group of patients these technical difficulties reinforce our conclusion that liver scanning has no place at present in the management of infants with obstructive jaundice.

In older children as in adults, the main value of the scan was in excluding or showing space-occupying lesions of greater than $2 \mathrm{~cm}$ in diameter in children presenting with hepatomegaly of uncertain cause. This observation may be crucial in assessing the necessity for further investigations such as arteriography, or liver biopsy directed at the spaceoccupying lesion. An important new observation in this series of patients with hepatic tumour is that the cold area on the $99 \mathrm{~m} \mathrm{Tc}$ scan which takes up selenomethionine 75 cannot necessarily be interpreted as a primary liver cell cancer since the haemangioendothelioma behaves similarly. Metastatic melanoma of the liver also takes up selenomethionine (Eddleston et al., 1971). Ultrasonic echography, serum alphafetoprotein determination, hepatic arteriography, and tissue diagnosis must thus complement liver scanning in the management of patients with spaceoccupying lesions.

In chronic liver disease there is a tendency for patients in each pathological group to show a particular pattern of uptake by the liver and spleen, such as the reduced liver size, peak count rate, and enlarged spleen in cirrhosis, but there is considerable overlap among the various pathological groups. In these children the main value of the scan is in confirming the presence of liver disease when the biochemical and clinical findings are equivocal, pointing to the necessity for more definitive investigations which cause some discomfort and carry slight risks such as liver biopsy. It is also of value when it is important to have a more precise measurement of liver and spleen size than the clinical estimate (Sullivan et al., 1976), as in the preoperative reduction of hepatic size in patients with glycogen storage disease treated by intravenous nutrition.

This study would not have been possible without the assistance of Drs. S. A. Osborne and J. J. Barrett, Department of Medical Physics and Nuclear Medicine.

\section{References}

Deligeorgis, D., Yannakos, D., and Doxiadis, S. (1973). Normal size of liver in infancy and childhood: x-ray study. Archives of Disease in Childhood, 48, 790-793.

Drum, D. E., and Christacopoulos, J. S. (1972). Hepatic scintigraphy in clinical decision making. Journal of Nuclear Medicine, 15, 908-915.

Eddleston, A. L. W. F., Rake, M. O., Pagaltsos, A. P., Osborn, S. B., and Williams, R. (1971). 75 SE-selenomethionine in the scintiscan diagnosis of primary hepatocellular carcinoma. Gut, 12, 245-249.

Feigelson, J., Pecau, Y., and Perez, R. (1972). Liver scanning and liver function in cystic fibrosis. Acta Paediatrica Scandinavica, 61, 337-342.

Goodchild, M. C., Banks, A. J., Drolc, Z., and Anderson, C. M. (1975). Liver scans in cystic fibrosis. Archives of Disease in Childhood, 50, 813-815.

Piepsz, A., Struyven, J., Decostre, P., and Maurus, R. (1974). La scintigraphie hépatosplénique dans les tumeurs du foie chez l'enfant. Helvetica Paediatrica Acta, 29, 371-382.

Samuels, L. D. (1971). Liver scans in chronic granulomatous disease of childhood. Pediatrics, 48, 41-50.

Sullivan, S., Krasner, N., and Williams, R. (1976). The clinical estimation of liver size: a comparison of techniques and an analysis of the source of error. British Medical Journal, 2, 1042-1043.

Correspondence to Dr. A. P. Mowat, Department of Child Health, King's College Hospital Medical School, Denmark Hill, London SE5 8RX. 